\title{
SUPPORTING THE ACADEMIC SUCCESS OF FIRST-YEAR \\ STUDENTS: A STUDY OF THE EPISTEMOLOGICAL ACCESS \\ THEY ACQUIRED THROUGH A LECTURE AND TEXT
}

\author{
L. Rusznyak* \\ e-mail: Lee.Rusznyak@wits.ac.za

\section{Dison*} \\ e-mail: Laura.Dison@wits.ac.za
}

\section{Moosa*}

e-mail: Moeniera.Moosa@wits.ac.za

\section{Poo*}

e-mail: Manono.Poo@wits.ac.za

*School of Education

University of the Witwatersrand

Johannesburg, South Africa

\section{ABSTRACT}

Much is at stake with regard to academic success of first-year students in higher education. This article presents the findings of an empirical study which looks at shifts in students' understanding of a concept through a systematic sequence of learning opportunities in a university-based course. While 89 per cent of participants could satisfactorily identify criteria of the concept following an introductory lecture, only 41 per cent could adequately articulate their understanding of that concept. One third of the participants did not read the prescribed text. For students who did the reading, lectures and the provision of reading materials provided sufficient opportunities for half of them satisfactorily to comprehend the requisite concepts. The findings reinforce the necessity of follow-up sessions to provide opportunities for concept consolidation and students adequately to articulate their understanding.

Keywords: higher education, lectures, pedagogy, epistemological access, scholarship of teaching and learning, concept development, scaffolding.

\section{INTRODUCTION}

The transformation of higher education in South Africa requires that opportunities to access higher education be made available to all deserving students. At present, there is much concern about the high drop-out rates of South African students, especially those in their first year of 
study (Council on Higher Education 2010). Given the moral imperative of transformation, along with a context of constraints on fiscal resources, South African universities are under increasing pressure to find ways to massify course offerings (Hornsby, Osman and de Matosala 2013). However, massification will only succeed if the sector works to support the academic success of students, particularly those in their first year of study. The higher education sector requires attention to both issues of formal access (that is, admission into an institution of higher learning) and epistemological access to the knowledge, skills and practices that need to be acquired through the offered curricula (Morrow 2007). Enabling the academic success of firstyear students is thus a crucial challenge for lecturers and an important area for research. Papers have been written on responding productively to student diversity (e.g. Smit 2012; Paxton and Frith 2015), and the factors that lead to some students being more 'at risk' of academic failure in higher education than others (e.g. Ramrathan, 2013). There is also a plethora of international and national literature that considers the benefits and drawbacks of offering coursework through lectures, as well as other modes of coursework delivery (e.g. Hornsby, Osman and De MatosAla 2013). Far less is known about how South African students entering higher education successfully acquire understanding of concepts through formal lectures in university-based courses.

This article reports on the first two of a sequence of three formal opportunities designed to provide students with epistemological access to a complex concept. Pre-service teachers' understanding of the concept of 'scaffolding' was assessed directly after an introductory lecture, and again once students had independently read a prescribed text on that concept. ${ }^{1}$ Directly after the lecture, nearly 90 per cent of students were able to correctly identify criteria of the concept and instances of its application in practice, however fewer than half were able adequately to articulate an understanding of the concept. We conclude that although lectures and reading of texts are a crucial beginning in introducing students to a concept, multiple extended opportunities for engagement are necessary if they are to comprehend that concept adequately. The findings of this study should be useful in informing moves to blended learning, particularly where higher education institutions are considering putting recordings of lectures on eLearning platforms in the hope that this extends access to the knowledge of the curriculum offered.

\section{ACCESS TO ESTABLISHED KNOWLEDGE THROUGH FORMAL COURSEWORK IN HIGHER EDUCATION}

University-based coursework, like any curriculum, should provide a systematic learning path that introduces students to non-intuitive ways of understanding the world and new ways of being 
that establish possibilities for transformation of the current reality. Introducing students to the basic concepts that make up a field of knowledge, and the networks of relationship between them, requires 'conscious reflection on and systematic investigation of established knowledge' (Slonimsky and Shalem 2006, 46). Through interactions with experts in the field and engagement with texts, students are systematically introduced to ideas that are distinct from common-sense ways of understanding (Craib 1992; Hirst 1973). It is through this guided process of distancing themselves from their subjective experiences and assumptions that students are formally and systematically introduced to distinctions and nuances that they had not previously noticed (Slonimsky and Shalem 2006). Distantiation establishes conditions for the acquisition of the kind of powerful knowledge that 'provides more reliable explanations and new ways of thinking about the world and acquiring it and can provide learners with a language for engaging in political, moral, and other kinds of debate' (Young 2008, 14). Guiding students through a process of distantiation is an important part of inducting them into the knowledge they are expected to acquire in higher education, and is particularly relevant in the design of first-year courses within undergraduate programmes.

When considering what it takes for novices to get to know a subject so that they can make inferences from that knowledge and intentionally use it for practical action, Winch $(2013,136)$ argues that 'minimal conceptual grasp is necessary for acquaintance with a subject and [is] thus a necessary, although by no means sufficient, condition for further progression in understanding and expertise'. The formal study of core concepts enables more systematic ways of thinking that can then be appropriated when thinking about contextual problems in conceptuallyinformed ways (Slonimsky and Shalem 2006). Appropriation of formal knowledge involves 'ordering and integrating conceptual resources derived from a broader body of work into one's own areas of concern, [and ...] understanding them in relation to what one already knows and making them one’s own' (Slonimsky and Shalem 2006). The capacity to articulate a concept in one's own words reflects the conceptual clarity needed for the development of conceptuallyinformed practices.

In the tradition of knowledge-for-practice (Cochran-Smith and Lytle 1999), the use of theoretical concepts to gain non-intuitive insights distantiates pre-service teachers from common-sense understandings of teaching and learning. Clarity of conceptual thinking establishes conditions for pre-service teachers, for example, to think about their developing practices in systematic and conceptually-informed ways, and ultimately develop the capacity to transform that knowledge into effective pedagogic interactions at the level of their developing classroom practice (Hirst 1973; Morrow 2007). The processes of distantiation and appropriation 
are crucial to supporting pre-service teachers develop conceptually-informed teaching practices.

\section{THE AFFORDANCES AND LIMITATIONS OF LECTURES IN HIGHER EDUCATION}

During their schooling, students in South Africa can generally succeed by performing rote learning of the materials that have been presented to them. Upon entry to university, the form of the knowledge presented to them is different, as lectures introduce concepts so as to enable students to access readings, but require that they engage with the concepts more deeply through independent reading of a wide range of texts. The disjuncture between the forms of teaching at school and university can make the transition from the one to the other exceedingly difficult for many students, especially when there is insufficient scaffolding to support the acquisition of new knowledge (Craig 1990). Craig urges lecturers not to shy away from their obligations to induct first year students into knowledge practices of higher education, but to do so with sufficient scaffolding that supports the transition of students from the ways of learning of school to those of university.

Formal lectures are considered to be a primary means of instruction in undergraduate courses (Hrepic, Zollman and Rebello 2007). They provide a scheduled time and space in which lecturers promote distantiation by introducing students to key concepts in systematic ways, and locate those concepts within a networked field of knowledge (Allias 2013). Lecturers create opportunities to point out those aspects that are particularly noteworthy, which novices might not see as significant, or would take a lot of time and effort to access in a short space of time (Ausubel 1963). Although lectures can engender a desire in students to learn more about the topic being presented (Allias 2013), they are not generally perceived as a space for them to partake in deeper discussion of the concepts introduced (Fry, Ketteridge and Marshall 2009, 22).

Research suggests that many students enter higher education institutions with a mistaken belief that university-based coursework consists of a stream of factual information to be memorised (Trigwell, Prosser and Waterhouse 1999; Fry, Ketteridge and Marshall 2009; Ramsden 2004). This misunderstanding of the nature of the knowledge they need to acquire leads them to adopt a 'surface-approach' to their learning. Nationally and internationally, concerns have been expressed that students mistakenly believe that lectures provide everything they are required to know about a topic. They do not understand that lectures, slides, texts and other learning support materials are merely a reduced representation of that knowledge. 
Students who misunderstand the nature and intention of lectures, which is to begin a process of deeper learning, are less likely to read prescribed texts (Doyle 2008). An effective lecture will stimulate students' understanding and interest so that they 'leave [the lecture] knowing that they have learned something, and are often inspired to go off and find out more' (Morton 2009, 59). A recent study found that most American university students spend less than two hours a week reading (Culver and Morse 2010). In order to enhance students' engagement with text-based realities, there are calls for courses to be designed in a way that makes active engagement with seminal readings compulsory in order for students to do well (Good and Brophy 2003; Ryan 2010; Romack 2010).

Critics of the pedagogy of lectures often do not distinguish between information (to be recalled) and complex knowledge (that has internal structure and relation). In his discussion of lectures, Summerlee $(2013,23)$ argues that lectures merely act as a vehicle for 'broadcasting information'. The imperative of the university to distantiate students from their common-sense understandings of phenomena, and acquaint them with the best-known knowledge established in a field thus far can thus be disregarded. Citing numerous studies from a time when behaviourism dominated educational thinking, he claims that there is a 'huge gap between successfully broadcasting information and that information being received, processed and understood' (Summerlee 2013, 23). Some believe that common-sense beliefs and possible misunderstandings may remain unchallenged in lectures (Ellis, Goodyear, O’Hara and Prosser 2007).

Bligh (1972) suggests that students have minimal cognitive engagement during lectures, because they are 'passive'. This position stems from a behaviourist view in which the role of knowledge is not recognised and overemphasises observable activity. The potential for lectures is recognised in other studies, but concern that understanding could easily be compromised because students are 'more likely to be thinking about something off-task' (Peterson and Miller 2004, 130). Other studies in learning insist that listening to lectures demands active cognitive processing (Ashwin, Boud, Coate, Hallett, Keane, Krause, Leibowitz, MacLaren, McArther, McCune and Tooher 2015; Allais 2013). These authors strongly contest the positions put forward by Bligh (1972) and Summerlee (2013).

There have been calls for lectures to be substantially reduced (and even abandoned altogether) in favour of problem-solving pedagogies (Gibbs 1992; Knight and Wood 2005; Summerlee 2013). Although problem-solving pedagogies might increase the apparent authenticity and contextual relevance of university-based coursework, we are concerned that such calls ignore how the absence of lectures would compromise students' acquisition of a 
systematised body of knowledge. In problem-solving approaches, the visibility of a conceptual object of study is reduced (Shalem and Rusznyak 2013), which would ultimately constrain students’ development of professional expertise (Winch 2013).

\section{'SCAFFOLDING' AS A POWERFUL CONCEPT IN THE PREPARATION OF PRE-SERVICE TEACHERS}

Students' understanding of the concept of 'scaffolding' is an appropriate conceptual object for studying their epistemological access to knowledge, because it is a non-intuitive concept that has a precise theoretical meaning and specific applications in practice. It has the potential to enable pre-service teachers to understand the work qualified teachers do in new, conceptuallyinformed ways. The term 'scaffolding' was introduced by Wood, Bruner and Ross in their 1976 study of tutoring interactions, where adults, as more knowledgeable 'others', guided children towards solving a problem by reducing the complexity of the task. For the purpose of this study, we understand scaffolding as a metaphor taken from the construction industry to describe structures that are put in place in order to build something, and continues to be required until that building has its own structural integrity. In the context of tutoring, the authors used scaffolding to describe the temporary support that adults provide children in order to assist them to do something they cannot yet manage independently. Cazden (1983) later linked scaffolding to Vygotsky’s (1962) concept of the Zone of Proximal Development from his cultural-historical theory of learning, and applied it to the work teachers do with learners. In the context of education, scaffolding is the structured support provided by a teacher who is regarded as the more knowledgeable other by virtue of specialised content and pedagogical knowledge of the subjects she teaches. The nature of the support depends on the task at hand, and needs to enable learners to complete that task successfully. The support provided is temporary and reduced over time as the learners' competence increases.

Instructional scaffolding is a valuable concept for pre-service teachers to access and understand both in its own right, and in the development of their teaching practice. As the 'more knowledgeable other' in the classroom, their clearly distilled understanding of the concept is the first step to enabling them to appropriate the learning to provide suitable scaffolds to support children’s learning in classroom contexts.

\section{CONTEXT OF THE STUDY}

This article is part of a larger study conducted in a school of education at an urban university. Participants were students in their first year of a Bachelor of Education degree. The study was 
located in a compulsory course in which students are formally introduced to the knowledgebased practices of teaching. During August of their first year of study, participants attended a lecture introducing them to the concept of scaffolding. The lecture focused on the historical development of the concept. The lecturer first introduced its use by describing the social mediation between parent and child (from Wood, Bruner and Ross 1976), and then explored how it has been applied to learning support provided by teachers to the learners they teach. At no point during the lecture were students given a formal definition of scaffolding, nor were they provided with an explicit list of its characteristics. Examples of its application in practice were intentionally left out. A diagnostic assessment instrument given to students at the end of the lecture sought evidence of their ability to extract the criteria of the object of study and then use these to distinguish examples of scaffolding from distracters. This required active cognitive engagement with the lecture, rather than an ability to recall information from slides presented. At the end of the lecture, students were given a hard copy of a reading by Hammond and Gibbons (2005) to prepare for the following week, together with questions to direct their reading of the text. The reading was carefully chosen; it demanded an intermediate level of reading ability. It also had the potential to consolidate students' understanding of scaffolding, and provide a basis for engagement in a follow-up tutorial session (the assessment of which is the subject of another paper).

\section{METHODOLOGY}

To track shifts in the understanding of students over time, we employed a mixed methods research design, with a quantitative component (to see general patterns within the group of participants) and qualitative data (to analyse changes in the responses of particular students over time with each successive intervention opportunity).

\section{Participants in the study}

With institutional ethics clearance for the study, 591 students in the first-year cohort were invited to participate in this study. Although 296 students gave their consent to participate, only 232 participated in the first and final phases of the study. It is this group who then constitute the sample for the statistical analysis. The participants represented a diverse group with respect to gender and schooling backgrounds. Upon entry into the institution, their academic literacy had been diagnostically assessed through an academic literacy component of the National Benchmarking Test (NBT) (Cliff 2015; Bharuthram 2012). The NBT assesses students' ability to read carefully and extract meaning from texts which are of the kind they will encounter 
during their studies in higher education. Those who score a 'proficient' rating should be able to cope with regular programmes of study without much augmented support. Those who score an 'intermediate' rating would benefit from specialised support to help them cope with the literacyrelated demands of their coursework. Those who obtain a 'basic' score in the NBT test are likely to require extensive, ongoing support to cope with the demands of university-based coursework. Disaggregated according to their literacy scores, we see from Table 1 that participants in this study represent a diverse group of students.

Table 1: An analysis of the biographical details of participants, disaggregated by academic literacy levels from their NBT scores

\begin{tabular}{|c|c|c|c|c|c|c|}
\hline & & $\begin{array}{l}\text { Students with } \\
\text { Basic literacy }\end{array}$ & $\begin{array}{l}\text { Students with } \\
\text { Intermediate } \\
\text { literacy }\end{array}$ & $\begin{array}{l}\text { Students with } \\
\text { Proficient } \\
\text { literacy }\end{array}$ & $\begin{array}{l}\text { Sub } \\
\text { total }\end{array}$ & Total \\
\hline \multicolumn{2}{|c|}{ Percentage of Participants } & $6.1 \%$ & $78.8 \%$ & $15.1 \%$ & & $100 \%$ \\
\hline \multirow{2}{*}{ Gender } & $\%$ Male & 1.4 & 21.3 & 4.3 & 27 & \multirow{2}{*}{$100 \%$} \\
\hline & $\%$ Female & 4.7 & 57.5 & 10.8 & 73 & \\
\hline \multirow{2}{*}{$\begin{array}{l}\text { Years out of } \\
\text { school }\end{array}$} & $\begin{array}{l}\% \text { Immediate entry } \\
\text { into university }\end{array}$ & 1.3 & 45.7 & 11.5 & 58 & \multirow{2}{*}{$100 \%$} \\
\hline & $\begin{array}{l}\% \text { Delayed entry into } \\
\text { university }\end{array}$ & 4.8 & 33.1 & 3.6 & 42 & \\
\hline \multirow{4}{*}{$\begin{array}{l}\text { Background of } \\
\text { own schooling }\end{array}$} & $\begin{array}{l}\% \text { Public school in a } \\
\text { township area }\end{array}$ & 2.8 & 39.4 & 3.0 & 45 & \multirow{4}{*}{$100 \%$} \\
\hline & $\begin{array}{l}\text { \% Public school in a } \\
\text { suburban area }\end{array}$ & 1.3 & 15.8 & 4.8 & 22 & \\
\hline & $\begin{array}{l}\% \text { Public school in a } \\
\text { rural area }\end{array}$ & 1.3 & 12.6 & 0 & 14 & \\
\hline & $\begin{array}{l}\% \text { Independent or } \\
\text { religious school }\end{array}$ & 0.7 & 11.0 & 7.3 & 19 & \\
\hline
\end{tabular}

In the presentation of the analysis of our data, we draw illustratively on the responses of two students, whom we shall refer to as Nomsa and Sipho. Nomsa attended a public suburban school, and Sipho attended a public township school. For Nomsa, teaching was her first choice of programme, but Sipho chose to register for a teaching degree as he was not accepted for his first choice of study. Both came to university directly after completing Grade 12. Nomsa scored a basic level of academic literacy on her NBT assessment, which implies that she would probably need extensive and ongoing support in order to obtain epistemological access to the knowledge offered in university-based coursework. On his entry into higher education, Sipho was found to have an intermediate literacy level, which would require some supplementary academic support.

\section{Data collection}

A diagnostic task to assess student understanding of the concept was devised by the team of researchers in conjunction with the lecturer. It consists of three sections (see appendix for the 
questions plus expected responses). First, students were asked to provide an open-ended articulation of their understanding of the concept of scaffolding. Their answer provides us with an articulation score. Combined, the second and third parts of the diagnostic assessment provide a recognition score. In part two, students were presented with a set of twelve statements. Each statement focused on one criteria of the concept of scaffolding. Students were required to state whether each given criteria was true or false in relation to scaffolding. In the third section, students were given a list of eight different examples of teachers' support of learning. They needed to draw on their understanding of the criteria for scaffolding, and indicate which of the eight examples meet the criteria for scaffolding.

To increase the validity of the diagnostic assessment instrument, an expert in learning theory (who was not a member of the research team) was asked to review the instrument, and to comment on its suitability for the purpose of assessing students' understanding of the concept. Recommendations for improving the diagnostic test received from the learning support specialist were implemented to strengthen it. The validity of our coding was checked, and the wording of the diagnostic task was scrutinised by a language specialist to ensure the clarity of the expression of items.

The three parts of the diagnostic assessment task were given to participants at three points in time. First, immediately after a lecture, secondly, one week later, after they had been given the requisite time to study the assigned reading with directed questions to answer, and thirdly, after a follow-up session. The results of the first two diagnostic assessments will be the focus of this article. Although students would have seen the questions before, in the second and third instance of them completing a part of the diagnostic assessment, their responses were collected immediately after completion. They therefore did not have access to the questions asked outside of the lecture hall or tutorial classroom beyond what they could remember. They were asked to respond to the questions in silence to ensure their own individual responses were not influenced by the understandings of their peers. Although participants were given a time limit of twenty minutes to complete the task, most required about ten to fifteen minutes to do so.

\section{DATA ANALYSIS AND CODING}

For the recognition tasks, the number of correct responses for the true/false questions (identification of criteria of scaffolding) and yes/no questions (identification of instances of scaffolding) were tallied. Students were awarded a recognition score out of twenty, as indicated in the appendix. Students' ability to articulate their understanding of the concept taught was rated out of a maximum of six points, one point being awarded for each of the defining criteria 
of scaffolding. These are:

- An indication that scaffolding involves the provision of support that reduces the complexity of a task

- An indication that scaffolding has a temporal dimension in that support is withdrawn when learners can do the task on their own

- An indication that scaffolding is provided by someone more knowledgeable, such as a teacher

- An indication that scaffolding results in the successful completion of a task

- An indication that scaffolding enables a learner to achieve more than what is possible without the support

- An indication that scaffolding has an affective dimension in that learners' frustration should be reduced as they tackle a challenging task with an appropriate degree of support One point was awarded for the presence of any of these characteristics in the students' responses, and these points culminated in an articulation score out of six. A score of two or less is considered to be indicative of unsatisfactory levels of epistemological access to the knowledge goods of the lecture.

Table 2: Translation device for interpreting changes in students' scores over time

\begin{tabular}{|l|l|l|l|}
\hline Coding categories & $\begin{array}{l}\text { Recognition } \\
\text { score (20) }\end{array}$ & $\begin{array}{l}\text { Articulation } \\
\text { score (6) }\end{array}$ & $\begin{array}{l}\text { Our } \\
\text { interpretation }\end{array}$ \\
\hline $\begin{array}{l}\text { Full epistemological access to knowledge goods } \\
\text { offered }\end{array}$ & $17-20$ & $5-6$ & Satisfactory \\
\hline $\begin{array}{l}\text { Substantial epistemological access to knowledge } \\
\text { goods offered }\end{array}$ & $13-16$ & $3-4$ & Unsatisfactory \\
\hline $\begin{array}{l}\text { Partial epistemological access knowledge goods } \\
\text { offered }\end{array}$ & $9-12$ & 2 & $0-1$ \\
\hline $\begin{array}{l}\text { Limited epistemological access to the knowledge } \\
\text { goods offered }\end{array}$ & $0-8$ & 0 \\
\hline
\end{tabular}

Having converted all biographical and qualitative responses into numerical form, we contracted an expert statistician to check for shifts in students' scores with each successive intervention, as well as for correlations between students' scores and aspects of their academic literacy levels and biographic details. We further requested interrogation of correlations between students' reading of the prescribed text and their subsequent diagnostic responses.

\section{LIMITATIONS OF THE STUDY}

It is necessary to acknowledge several limitations of this study. First, we acknowledge that full epistemological access to a complex concept cannot be fully gained through attendance of one introductory lecture and engagement with one prescribed reading. Any single lecture, reading 
or tutorial task can, at best, offer students an inherently circumscribed representation of a concept. We recognise that multiple representations are needed to develop a robust conceptual understanding. Our study therefore cannot claim to investigate students' comprehensive understanding of the concept, but we can investigate epistemological access to the knowledge goods offered by this lecture and the prescribed reading. A second limitation which needs to be acknowledged is related to the fact that understanding is a cognitive process of the mind. Cognitive processes are complex, and they involve the acquiring, organising, manipulating and using of knowledge (Bransford, Brown \& Cocking, 2000). As a result, student understanding cannot be observed or directly measured. We therefore rely on representations of understanding such as the captured responses by students to diagnostic assessment tasks as a proxy for accessing their levels of understanding. Thirdly, the analysis was carried out in relation to one concept with one cohort of students in one course at a particular university. This constrains the generalisability of findings from this study. Fourthly, it is possible that variables affecting the participation of students in this research project may have skewed the results. They may have concentrated harder, for example, knowing they would be completing a diagnostic assessment at the end of the lecture. Although they completed the diagnostic assessment task individually, it is possible that they discussed their answers with one another outside of the lecture. For these reasons, we acknowledge that our findings are both partial and provisional.

\section{FINDINGS}

We present our analysis of the data in two main sections. First, we present our analysis of the student responses to the diagnostic assessment instrument directly after attending a lecture. In the second section, we present our analysis of their responses a week later, having had an opportunity to read a prescribed text, and review any notes taken during the lecture.

\section{Student engagement with an introductory lecture on scaffolding}

We have found a large discrepancy between the number of participants who could satisfactorily recognise criteria for scaffolding and instances of its application in practice (89,7\%) and the number who could satisfactorily articulate their understanding of the concept (41.0\%). We will now unpack these results in more detail.

Table 3: Summary of epistemological access to the knowledge goods offered by the lecture demonstrated by participants, shown in percentages $(n=232)$

\begin{tabular}{|l|l|l|l|l|}
\hline $\begin{array}{l}\text { Epistemological access to } \\
\text { knowledge goods of lecture }\end{array}$ & \multicolumn{2}{l|}{ Recognition tasks } & \multicolumn{2}{l|}{ Articulation task } \\
\hline Full epistemological access & $34.5 \%$ & $89.7 \%$ of participants & $0.9 \%$ & $41.0 \%$ of participants \\
\hline
\end{tabular}




\begin{tabular}{|l|l|l|l|l|}
\hline $\begin{array}{l}\text { Epistemological access to } \\
\text { knowledge goods of lecture }\end{array}$ & \multicolumn{2}{|l|}{ Recognition tasks } & \multicolumn{2}{l|}{ Articulation task } \\
\hline $\begin{array}{l}\text { Substantial epistemological } \\
\text { access }\end{array}$ & $55.2 \%$ & $\begin{array}{l}\text { demonstrate satisfactory } \\
\text { recognition }\end{array}$ & $40.1 \%$ & $\begin{array}{l}\text { demonstrate satisfactory } \\
\text { articulation }\end{array}$ \\
\hline Partial epistemological access & $9.1 \%$ & $\begin{array}{l}10.3 \% \text { of participants } \\
\text { demonstrate } \\
\text { unsatisfactory recognition }\end{array}$ & $33.2 \%$ & $\begin{array}{l}59.0 \% \text { of participants } \\
\text { demonstrate } \\
\text { unsatisfactory recognition }\end{array}$ \\
\hline Limited epistemological access & $1.2 \%$ &
\end{tabular}

\section{Student responses to the recognition tasks}

The vast majority of participants (89.7\%) demonstrated a satisfactory ability to identify criteria of scaffolding and distinguish instances of its application in practice from attending the lecture. For this part of the diagnostic test, the median score was sixteen (IQR 14-17; with the range between six and twenty). While no student scored five or less in this section, three students (i.e. $1.2 \%$ of the participants) demonstrated limited epistemological access to the concept taught.

The finding that on the basis of attending an introductory lecture, nearly 90 per cent of participants could correctly identify characteristics and instances of scaffolding from distracters suggests that students do actively engage with concepts during formal lectures. Nomsa was one of the twenty four students who did not demonstrate satisfactory access to the concept in the lecture. She scored eleven for recognition tasks, demonstrating partial access. Sipho scored $19 / 20$, and was one of the 89.7 per cent who demonstrates satisfactory access to the goods of the lecture.

\section{Students' responses to the articulation task}

Despite their ability to distinguish valid criteria of scaffolding, fewer than half of the participants (41.0\%) could articulate the main attributes of scaffolding in a comprehensive and coherent manner directly after the introductory lecture, and a quarter of participants (25.8\%) could demonstrate limited epistemological access to the concept. In her first attempt to articulate her understanding, Nomsa said scaffolding 'means to build learners in the way that you teachers you want them to be by shaping them until they become what you want them to be'. This response was given an articulation score of zero. Nomsa's response does not pick up on any of the ideas discussed in the lecture, and she draws on her everyday knowledge of teaching to respond. In contrast, Sipho was one of the 95 participants who, by the end of the lecture, was able satisfactorily to articulate his understanding of scaffolding, responding as follows: 'Scaffolding means that a teacher provides support to the learners by helping them on doing the task that they cannot do on their own and a teacher makes things clear and reduces confusion to learners'. This response scored a five on the coding system we used.

If we present this finding in the form of a matrix, we define four quadrants, based on the extent to which students obtained see: 
Table 4: Table showing how students performed in recognition and articulation tasks after the lecture

\begin{tabular}{|c|c|c|c|c|}
\hline \multirow{2}{*}{\multicolumn{2}{|c|}{ After a lecture }} & \multicolumn{2}{|c|}{$\begin{array}{l}\text { Degrees of epistemological access } \\
\text { (as demonstrated by articulation task) }\end{array}$} & \multirow{3}{*}{$\begin{array}{l}\text { Totals } \\
208 \\
(89.7 \%) \\
\end{array}$} \\
\hline & & Satisfactory & Unsatisfactory & \\
\hline \multirow{2}{*}{$\begin{array}{l}\text { Degrees of } \\
\text { epistemological access } \\
\text { (as demonstrated by } \\
\text { recognition tasks) }\end{array}$} & Satisfactory & $\begin{array}{l}92 \text { students including } \\
\text { Sipho }(39.7 \%)\end{array}$ & $116(50.0 \%)$ & \\
\hline & Unsatisfactory & $3(1.3 \%)$ & $\begin{array}{l}21 \text { students including } \\
\text { Nomsa }(9.1 \%)\end{array}$ & $24(10.3 \%)$ \\
\hline & 95 (40.9\%) & $137(59.1 \%)$ & $\begin{array}{l}232 \\
(100.0 \%)\end{array}$ \\
\hline
\end{tabular}

Students who were unable to recognise which statements were indicative of scaffolding were also unlikely to be able to articulate the concept. However, the converse does not hold true. Nearly 85 per cent of students in this study who were able to correctly identify criteria for scaffolding and distinguish examples of it experienced difficulty in articulating their understanding of the concept straight after the lecture. Only 39.7 per cent of participants (including Sipho) were able both to identify and apply criteria, and articulate their understanding of the concept satisfactorily from the input of the lecture. This group of ninetytwo students was found to be diverse but representative of the group of participants in the study. It contained students whose academic literacy levels ranged from basic to proficient in proportions similar to those of the broader group of participants. It also reflected a similar profile of students who had undertaken their schooling in suburban, township and rural school contexts. In addition, the group of ninety-two reflected a similar gender profile to that of the group as a whole. It reflected a similar proportion of students for whom teaching was their first choice of programme, as well as a comparable percentage of students who had registered for teaching for a variety of other reasons. This study could therefore not find any statistically significant biographical factor that accounts for why some participants accessed the knowledge goods of the lecture better than others.

We now turn our attention to the 50.0 per cent of students who experienced difficulty articulating the concept, despite evidence from their recognition score that they understood it fairly well. We wanted to establish whether students' academic literacy level upon their entry into higher education correlated with their ability to understand and articulate the concept. A Fisher's exact test revealed no significant association between scores on students' articulation tasks and their academic literacy scores from the NBT assessment administered upon their entry into the institution (Fisher's exact test: $\mathrm{p}=0.074$ ). Similarly, there was no significant relationship between students' scores on the recognition tasks and their academic literacy classification (Fisher's exact test: $\mathrm{p}=0.18$ ). Despite our expectations, there is no evidence from this study to support an argument that students' conceptual clarity derived from lectures is linked to the 
levels of academic literacy that they demonstrated on entry into higher education.

\section{Student understanding supported by an independently studied reading}

One week after the introductory lecture, it was expected that students would have read the prescribed text with which they were provided. However, only 62.2 per cent of participants (including both Nomsa and Sipho) indicated that they had engaged with the reading. Twentyseven of these, however, did not participate in the second round of diagnostic testing. The sample group for this part of the analysis therefore drops from 232 to 116 participants.

Table 5: Degree of epistemological access to the lecture and reading by participants, shown in percentages $(n=116)$

\begin{tabular}{|l|l|l|l|l|}
\hline $\begin{array}{l}\text { Degree of epistemological } \\
\text { access to the knowledge } \\
\text { goods offered by the lecture } \\
\text { and reading }\end{array}$ & \multicolumn{2}{|l|}{ Recognition score } & \multicolumn{2}{|l|}{ Articulation score } \\
\hline Full epistemological access & $32.2 \%$ & $\begin{array}{l}93.1 \% \text { of participants } \\
\text { now demonstrate } \\
\text { satisfactory recognition } \\
\text { ability }\end{array}$ & $8.6 \%$ & $\begin{array}{l}54.3 \% \text { of participants } \\
\text { now demonstrate } \\
\text { satisfactory articulation } \\
\text { ability }\end{array}$ \\
\hline $\begin{array}{l}\text { Substantial epistemological } \\
\text { access }\end{array}$ & $60.9 \%$ & $\begin{array}{l}6.9 \% \text { of participants } \\
\text { still demonstrate } \\
\text { unsatisfactory } \\
\text { recognition ability }\end{array}$ & $19.8 \%$ & $\begin{array}{l}45.7 \% \text { of participants } \\
\text { still demonstrate } \\
\text { unsatisfactory } \\
\text { articulation ability }\end{array}$ \\
\hline Partial epistemological access & $6.9 \%$ & $25.9 \%$ & \\
\hline Limited epistemological access & $0.0 \%$ & &
\end{tabular}

It is possible that the statistical analysis found no significant change in the recognition scores of students because a large number of students did not prepare the reading task. The mean change in score between the results of the diagnostic test straight after the lecture and those tallied a week later, once students had engaged with a provided reading, was 0.0 points (95\% CI: -0.3 to 0.3 ). There was no significant increase in Recognition score (paired t-test: $p=0.90$ ). The scores of twelve students moved from partial/limited access range to the substantial/full epistemological access range, while ten moved in the opposite direction (McNemar's test: $\mathrm{p}=0.67)$.

Over the whole group (including those who had not done the independent reading), there was a significant change in the levels of epistemological access, which was demonstrated through ability to articulate understanding: forty-two students moved from an unsatisfactory articulation score to a satisfactory one, while only seven moved in the opposite direction (McNemar's test: $\mathrm{p}<0.0001$ ).

Of the sixty-six students who had not articulated an adequate understanding of the concept directly after the lecture, thirty of them were able to satisfactorily articulate the concept once they had independently read the assigned text. We are especially interested in the progress of the twenty-one participants (including Nomsa) who demonstrated an unsatisfactory 
understanding of the concept through both articulation and recognition scores after the introductory lecture. Five of these students did not attend class the following week, and so we have no diagnostic data of shifts in their understanding of the concept. As for the remaining sixteen students, three of them (one of whom had attempted the reading) scored within the same analytic categories as they had done immediately after the lecture. Two improved their articulation score but not their recognition score, despite one having not done the reading. Three improved their recognition score but not their articulation score, even though only one of the three had attempted the reading. There were six students (including Nomsa) who now scored in the satisfactory range in both the articulation and recognition tasks, after having read the text. These six students thus shifted from the unsatisfactory recognition/articulation quadrant to the satisfactory recognition/articulation quadrant.

After reading the prescribed text, Nomsa's articulation of the concept of scaffolding was significantly improved. She wrote the following: 'Scaffolding in the context of teaching means that the teacher has to give support to the learners for a certain period of time, the teacher support learners until they are able to do the task on their own'. After engaging with the reading, she was able to include reference to the temporary nature (1) of support (1) provided by the teacher (1), and mention that this support leads to task completion (1) and promotes learner independence (1). Her articulation score thus increased from zero (directly after the lecture) to five (having done the reading independently). Nomsa's recognition score also increased from eleven (directly after the lecture) to eighteen (having read the prescribed text). Despite the prediction, based on her NBT score, that she would probably require individualised support to manage with the literacy demands of studies, the evidence of this study suggests that while Nomsa gained limited epistemological access to the concept during the lecture, she was able to use the reading, access to the lecture slides and her own notes to gain satisfactory understanding of the concept with time and considerable effort on her part.

Table 6: Table showing how students performed in recognition and articulation tasks after the lecture and the reading

\begin{tabular}{|l|l|l|l|l|}
\hline \multirow{2}{*}{$\begin{array}{l}\text { After a lecture and } \\
\text { independently reading a text }\end{array}$} & \multicolumn{2}{|l|}{$\begin{array}{l}\text { Degrees of epistemological access } \\
\text { (as demonstrated by articulation task) }\end{array}$} & \multirow{2}{*}{ Totals } \\
\cline { 2 - 5 } & Satisfactory & Unsatisfactory & \\
\hline $\begin{array}{l}\text { Degrees of } \\
\text { epistemological } \\
\begin{array}{l}\text { access (as } \\
\text { demonstrated by } \\
\text { recognition task) }\end{array}\end{array}$ & Satisfactory & $\begin{array}{l}60 \text { students including both Sipho } \\
\text { and Nomsa } \\
(51.7 \%)\end{array}$ & $48(41.4 \%)$ & $\begin{array}{l}108 \\
(93.1 \%)\end{array}$ \\
\cline { 2 - 5 } TOTALS & $4(3.4 \%)$ & $4(3.4 \%)$ & $8(6.9 \%)$ \\
\hline
\end{tabular}

Although there is some quantifiable increase in epistemological access of the concept through 
the support of an independent reading with directed questions, it is still a concern that in terms of their ability to articulate an understanding of the concept, just over half the class (55.2\%) achieved satisfactory epistemological access to the knowledge goods offered. After attending a lecture and the directed self-study of a reading, just over half the class (51.7\%) was able to demonstrate their full/substantial epistemological access through their responses to the articulation and recognition tasks.

\section{DISCUSSION}

There are several important findings from this study that need careful consideration if epistemological access for first-year students in higher education is to be enhanced. First, the findings of our study contest the claim by Summerlee (2013) that lectures simply entail the broadcasting of information. Despite the lecture not having explicitly covered criteria of scaffolding and instances of its practical use, it is significant that immediately after an introductory lecture, nearly 90 per cent of participants could recognise both. While this was only the students' initial introduction to the complex concept, their responses suggest an understanding well beyond mere recall, and an active engagement with the knowledge goods of the lecture. This finding strongly contests the assertion that lectures are generally ineffective because students tend to be thinking about something unrelated (Peterson and Miller 2004).

Our analysis of the data shows a significant discrepancy between the recognition part of the diagnostic assessment, and the part where students had to articulate the essence of the concept for themselves. This finding suggests that if students are given a self-assessment test with a series of recognition-type questions, they are likely to score highly. Our study suggests that the kinds of interactive tasks that can be incorporated into large class lectures, which are advocated by Ashwin et al. (2015) and Biggs and Tang (2011), would probably have provided convincing evidence of student understanding.

The ability of students to score highly on recognition-type tasks may lead students and lecturers alike to (incorrectly) deduce that there has been sufficient understanding of the lecture. Our finding that recognition does not necessarily translate into an ability to articulate a concept highlights the importance of a formal space for students to engage with concepts as objects worthy of study in their own right in ways that supplement the lecture. We therefore support Ritchie’s $(2016,4)$ call for the intentional creation of learning spaces in which students can engage explicitly with key concepts, 'space for them to respond to an impetus, to question and to explore'. In this study, a lecture and a text provided a frame for acquisition of criteria, but there was not a space in which students could develop their capacity for articulation of their 
understanding. The lecture and text provided sufficient instruction for just over half the class to demonstrate satisfactory understanding of the concept through recognition and articulation. Communal learning spaces could afford greater opportunities for students to articulate their understanding and clarify misconceptions.

It is a concern that even in a context where students are held to account in terms of their preparation for tutorials, 37.8 per cent of participants admitted that they had not completed the tutorial preparation (independent reading) expected of them. This confirms the concern expressed by Culver and Morse (2010) about the assumption of students that attending lectures is sufficient for epistemological access. Those students who ignored the reading have not yet come to understand what it means to be a student in a higher education context in terms of the value of established knowledge, the importance of meaning-making, taking responsibility, and engaging purposively with the learning opportunities offered.

\section{CONCLUSION}

This study shows, definitively, that first-year students in this study were able to access a new concept, with some level of understanding (albeit at the level of recognition) through the provision of a formal lecture. It enabled students to access concepts that have transformative power. Despite their limitations, lectures are clearly a very accessible form of pedagogy to students entering into the higher education system presently. Calls to eliminate well-constructed lectures from university-based pedagogy would ultimately compromise a highly effective means of distantiating students from their common-sense understandings of concepts, and introducing them to established knowledge. While the provision of lectures (live or recorded) and access to relevant texts enables students to recognise criteria of a new concept, these pedagogies only enable half of students adequately to articulate this understanding. The provision of live or online recordings of lectures with notes that refer students to supporting texts is important, but insufficient, for enabling satisfactory epistemological access. The provision of intentionally designed opportunities for students to articulate their understanding cannot be regarded as an additional measure, but needs to be a standard part of learning opportunities for first-year students in the South African context.

\section{ACKNOWLEDGEMENT}

The authors wish to acknowledge funding from the DHET Teaching Development Grant that made this study possible. We also wish to acknowledge the assistance of Rashad Bagus in providing valuable input in the research design. 


\section{NOTE}

1. The second article will focus on shifts in their understanding once they had participated in the third intervention, a subsequent consolidation session.

\section{REFERENCES}

Allais, S. 2013. Losing contact - How can we teach large classes? In Large-class pedagogy: Interdisciplinary perspectives for quality higher education, ed. ed. D. Hornsby, R. Osman and J. De Matos-Ala, 33-48. Stellenbosch: Sun Press.

Ashwin, P., D. Boud, K. Coate, F. Hallett, E. Keane, K. L. Krause, B. Leibowitz, I. MacLaren, J. McArther, V. McCune and M. Tooher. 2015. Reflective teaching in higher education. London: Bloomsbury Publishing.

Ausubel, D. 1963. The psychology of meaningful verbal learning: An introduction to school learning. New York: Grune \& Stratton.

Biggs, J. and C. Tang. 2011. Teaching for quality learning at university: What the student does. Maidenhead: Open University Press and Society for Research into Higher Education.

Bharuthram, S. 2012. Making a case for the teaching of reading across the curriculum in higher education. South African Journal of Education 32: 205-214.

Bligh, D. 1972. What's the use of lectures? Middlesex, England: Penguin.

Bransford, J., Brown, A. \& Cocking, R. 2000. How People Learn: Brain, Mind, Experience and School. Washington, D.C: National Academy Press.

Cazden, C. 1983. Adult assistance to language development: Scaffolds, models, and direct instruction. In Developing literacy: Young children's use of language, ed. R. Parker and F. Davis, 3-17. Newark, DE: International Reading Association.

Cliff, A. 2015. The National Benchmark Test in Academic Literacy: How might it be used to support teaching in higher education? Language Matters 46(1): 3-21.

Cochran-Smith, M. and S. Lytle. 1999. Relationships of knowledge and practice: Teacher learning in communities. Review of Research in Education 24: 249-305. American Educational Research Association.

Council on Higher Education. 2010. Report on the National Review of Academic and Professional Programmes in Education. Pretoria.

Craib, I. 1992. Modern social theory: From Parsons to Habermas. New York Harvester Wheatsheaf.

Culver, T. F. and L. W. Morse. 2010. Helping students use their textbooks more effectively. Faculty focus special report. 11 Strategies for getting students to read what's assigned. Reproduced from The Teaching Professor, Oct. 2006: 7-8. USA: Magna Publications Inc.

Doyle, T. 2008: Helping students learn in a learner-centered environment: A guide to facilitating learning in Higher Education. United States of America: Stylus Publishing, LLC.

Ellis, R. A., P. Goodyear, A. O'Hara and M. Prosser. 2007. The university student experience of faceto-face and online discussions: Coherence, reflection and meaning. ALT-J: Research in Learning Technology 15(1): 83-97.

Fry, H., S. Ketteridge and S. Marshall. 2009: A handbook for teaching and learning in Higher Education: Enhancing academic practice. New York: Routledge.

Gibbs, G. 1992. Control and independence. In Teaching large classes in higher education: How to maintain quality with reduced resources, ed. G. Gibbs and A. Jenkins, 37-62. London: Kogan.

Good, T. and J. Brophy. 2003. Looking in classrooms. New York: Macmillan.

Hammond, J. and P. Gibbons. 2005. Chapter 2: What is scaffolding? In Teachers' voices 8: Explicitly supporting reading and writing in the classroom, ed. A. Burns and H. de Silva Joyce, 8-16. Sydney: National Centre for English Language Teaching and Research. 
Hirst, P. H. 1973. Liberal education and the nature of knowledge. In Philosophy of education, ed. R. S. Peters. Oxford.

Hornsby, D., R. Osman and J. de Matos-ala. 2013. Teaching large classes: Quality education despite the odds. In Large-class pedagogy, ed. D. Hornsby, R. Osman and J. de Matos-ala, 7-11. Stellenbosch: Sun Press.

Hrepic, Z., D. A. Zollman and S. N. Rebello. 2007. Comparing students and experts' understanding of the content of a lecture. Journal of Science and Educational Technology 16(3): 213-224.

Knight, J. K. and W. B. Wood. 2005. Teaching more by lecturing less. Cell Biology Education 4(4): 298-310.

Morrow, W. 2007. Learning to teach in South Africa. Pretoria: HSRC Press.

Morton, A. 2009. Lecturing to large groups. In A handbook for teaching and learning in Higher Education: Enhancing academic practice, ed. H. Fry, S. Ketteridge and S. Marshall, 58-71. Third Edition. New York: Routledge.

Paxton, M. and V. Frith. 2015. Transformative and normative? Implications for academic literacies research in quantitative disciplines. In Working with academic literacies. Case studies towards transformative practice, ed. T. Lillis, K. Harrington, M. Lea and S. Mitchell. Colorado, The WAC Clearinghouse and South Carolina, Parlor Press.

Peterson, S. E. and A. M. Miller. 2004: Comparing the quality of students' experiences during cooperative learning and large group instruction. The Journal of Educational Research 97(3): 123-134.

Ramrathan, L. 2013. Towards a conceptual framework for understanding student dropout from HEIs. South African Journal of Higher Education, 27(1), 209-220.

Ramsden, P. 2004. Learning to teach in higher education. New York: Routledge.

Ritchie, L. 2016. Fostering self-efficacy in higher education students. UK: Palgrave.

Romack, J. L. 2010. Enhancing students' readiness to learn. Faculty focus special report. 11 strategies for getting students to read what's assigned. Reproduced from The Teaching Professor Oct 2006: 4-5. USA: Magna Publications Inc.

Ryan, T. E. 2010. What textbook reading teaches students. Faculty focus special report. 11 strategies for getting students to read what's assigned. Reproduced from The Teaching Professor Oct 2006: 5-6. USA: Magna Publications Inc.

Shalem, Y. and L. Rusznyak. 2013. 'Theory' for teacher practice: A typology of application tasks in teacher education. South African Journal of Higher Education 27(5): 1118-1134.

Smit, R. 2012. Towards a clearer understanding of student disadvantage in higher education: Problematising deficit thinking. Higher Education Research \& Development 31(3): 369-380.

Slonimsky, L. and Y. Shalem. 2006. Pedagogic responsiveness for academic depth. Journal of Education 40: 35-58.

Summerlee, A. 2013. Lectures - Do we need them at all? In Large-class pedagogy: Interdisciplinary perspectives for quality higher education, ed. D. Hornsby, R. Osman and J. De Matos-Ala, 2131. Stellenbosch: Sun Press.

Trigwell, K., M. Prosser and F. Waterhouse. 1999. Relations between teachers' approaches to teaching and students' approaches to learning. Higher Education 37: 57-70.

Vygotsky, L. S. 1962. Thought and language Cambridge, Mass: MIT Press.

Winch, C. 2013. Curriculum design and epistemic ascent. Journal of Philosophy of Education 47(1): 128-146.

Wood, D. J., J. S. Bruner and G. Ross. 1976. The role of tutoring in problem solving. Journal of Child Psychiatry and Psychology 17(2): 89-100.

Young, M. 2008. Bringing knowledge back in. From social constructivism to social realism in the sociology of education. London and New York: Routledge. 


\section{Appendix: Diagnostic Assessment tasks}

\section{ARTICULATION TASK:}

What does scaffolding mean in the context of teaching?

See criteria for coding of responses in methodology section

\section{RECOGNITION TASKS}

1. Indicate whether you think the following statements about scaffolding are TRUE or FALSE by placing a CROSS $(X)$ in the appropriate block.

\begin{tabular}{|c|c|c|c|}
\hline & & TRUE & FALSE \\
\hline a. & A teacher who scaffolds designs tasks that learners are able to manage on their own. & & $\mathrm{X}$ \\
\hline o. & $\begin{array}{l}\text { The provision of scaffolding should mean that learners don't feel frustrated or overwhelmed } \\
\text { when completing classwork tasks. }\end{array}$ & $\mathrm{X}$ & \\
\hline C. & $\begin{array}{l}\text { Scaffolding provides learners with as much support as they need until they can do the task on } \\
\text { their own. }\end{array}$ & $\mathrm{X}$ & \\
\hline d. & Teachers scaffold when they expect learners to complete tasks at their level of ability. & & $\mathrm{X}$ \\
\hline e. & Scaffolds are provided so that learners avoid making common mistakes when doing the tasks. & $\mathrm{X}$ & \\
\hline f. & Learners can provide scaffolds for their own learning. & & $\mathrm{x}$ \\
\hline g. & With scaffolding, children can complete tasks that they wouldn't be able to do by themselves. & $\mathrm{X}$ & \\
\hline $\mathrm{h}$ & $\begin{array}{l}\text { A teacher may provide more scaffolding to some learners than others so that all of them can } \\
\text { complete a task successfully. }\end{array}$ & $\mathrm{X}$ & \\
\hline . & $\begin{array}{l}\text { The teacher who uses scaffolding lets learners try a task by themselves and only helps them } \\
\text { when asked to do so. }\end{array}$ & & $X$ \\
\hline & $\begin{array}{l}\text { Scaffolding is reduced over time so that learners can manage similar tasks more } \\
\text { independently. }\end{array}$ & $x$ & \\
\hline & $\begin{array}{l}\text { Successful scaffolding depends on the teacher having a good knowledge of the abilities of } \\
\text { learners. }\end{array}$ & $X$ & \\
\hline & $\begin{array}{l}\text { For a teacher to design scaffolding effectively, he/she needs clearly to understand the cognitive } \\
\text { demands of the task. }\end{array}$ & $X$ & \\
\hline
\end{tabular}

2. Which of the following examples of teacher support do you think are examples of scaffolding? Provide reason/s for your answer in the space provided.

\begin{tabular}{|c|c|c|c|}
\hline & & & \\
\hline & $\begin{array}{l}\text { Introduce and explain the meaning of difficult } \\
\text { words in a reading passage before learners read it. }\end{array}$ & YES & $\begin{array}{l}\text { Scaffolding provides enough support so that all } \\
\text { learners are able to complete the same task. }\end{array}$ \\
\hline b. & $\begin{array}{l}\text { Different reading texts (some basic and others } \\
\text { more advanced) are provided to learners with } \\
\text { different reading abilities. }\end{array}$ & NO & $\begin{array}{l}\text { Scaffolding provides enough support so that all } \\
\text { learners are able to complete the same task. }\end{array}$ \\
\hline & $\begin{array}{l}\text { Break a task into several smaller steps, and asking } \\
\text { learners to complete one step at a time. }\end{array}$ & YES & It reduces the complexity of the task \\
\hline d. & $\begin{array}{l}\text { Demonstrate how to solve a mathematic problem, } \\
\text { before learners solve similar problems in partners } \\
\text { or on their own. }\end{array}$ & YES & $\begin{array}{l}\text { Modelling of a pathway towards solving a } \\
\text { problem }\end{array}$ \\
\hline & $\begin{array}{l}\text { Group learners according to their abilities and } \\
\text { allocate different activities for each group to } \\
\text { complete. }\end{array}$ & NO & $\begin{array}{l}\text { Scaffolding provides enough support so that all } \\
\text { learners are able to complete the same task. }\end{array}$ \\
\hline f. & $\begin{array}{l}\text { The headings and structure of a graphic organizer } \\
\text { (e.g. concept map or table of comparison) are } \\
\text { provided to children as a frame for their classwork. }\end{array}$ & YES & It reduces the complexity of the task \\
\hline g. & $\begin{array}{l}\text { Give learners questions that help them focus } \\
\text { attention on relevant parts of a reading text. }\end{array}$ & YES & It reduces the complexity of the task \\
\hline & $\begin{array}{l}\text { Give learners a topic to research as an } \\
\text { independent self-study project. }\end{array}$ & NO & No social mediation in the learning. \\
\hline
\end{tabular}

